\title{
Job Satisfaction: Determinant And Effect Of Interact With Spirituality To Lecturers'performance
}

\author{
Sardiyo $^{1}$, Toto Sugiharto ${ }^{2}$, Maulana $^{3}$ \\ \{sardiyo.kartoprawiro@gmail.com ${ }^{1}$, tsharto@staff.gunadarma.ac.id², Maulana_57@ymail.com ${ }^{3}$ \} \\ ${ }^{1}$ Graduate Program of Magister Management, STIE MURA, Lubuklinggau Indonesia \\ ${ }^{2}$ Department of Management, Gunadarma University, Jakarta Indonesia \\ ${ }^{3}$ Graduate Program of MIP, Tamansiswa Palembang University, Palembang, Indonesia
}

\begin{abstract}
This research was aimed to find out the influence of leadership, organizational culture, motivation and competence toward lecturers' job satisfaction; and the influence of job satisfaction, job satisfaction moderated by spirituality toward lecturers' performance. There were 250 respondents from private higher education as the sample. In collecting the data, questionnaire was used. Structural Equation Model (SEM) was used to analyze the data. The results showed that; 1) simultaneously, leadership style, organizational culture, motivation and lecturers' competence had significant influence to job satisfaction. 2) Partially, leadership style, organizational culture, and motivation had no significant influence to job satisfaction, while the lecturers' competence had significant influence to job satisfaction. 3) Job satisfaction, job satisfaction moderated by spirituality significantly influenced lecturers' performance.
\end{abstract}

Keywords: Job Satisfaction, Lecturers' Performance, Lecturers' Competence, Motivation, Spiritual.

\section{Introduction}

Government Regulation No. 37 of 2009 on lecturers states that lecturers are professional educators and scientists with the main task of transforming, developing and disseminating science, technology and art through education, research and community service.Lecturers must have motivation in the field of Three Principles of Higher Education and give a good example. Lecturers are professionals who must have a set of competencies, among others; Academic, Pedagogical, Social, Personality, and Institutional. Based on Government Regulation No. 37 of 2009 on lecturers, Chapter I Article 1 paragraph (1) Lecturers are professional educators and scientists with the main task of transforming, developing and disseminating science, technology and the arts through education, research, and community service. Implementation of the main task of lecturer should be evaluated and reported periodically as a form of lecturers' performance accountability to the stakeholders (MoNE, 2010). (Chen, 2004), (Hukpati, 2009), (Gibson et al., 2014), (Delobbe, 2002), (Davis and Newstrom, 1997).This explanation indicates that the performance of the lecturer is the ability to carry out the work or tasks held by the lecturer in completing a job. External factors include behaviors, attitudes, and actions of co-workers, organizational climate and so on.

Data from Kopertis Region II indicates that the performance of lecturers in Kopertis Region II, South Sumatra region has not achieved expectation. By the total lecturers of 6.375 people in 213 Private Higher Education, 2.251 lecturers are in the level of undergraduate, while 4.486 lecturers are in the level of graduate (master), and 227 lecturers are in the level of postgraduate (doctoral) education qualifications. This shows that since the enactment of the law on teachers, lecturers, and other regulations concerning lecturers until 2015, all the 
lecturers teaching in universities must qualify at least a master or second degree (S.2). This shows that the competence of lecturers in Kopertis Region II of South Sumatra is still not as expected.(Ali, 2013), (King and Decicco, 2009), (Spencer and Spencer, 1993), (Selman et al., 2005), (Moon, 2000). Another factor that implicitly affects the performance of a lecturer in a college is a factor of spirituality that generally relates to the belief and /or trust of the lecturer on the essence of his/her work. Based on the background explained above, the research problems are formulated as follows:

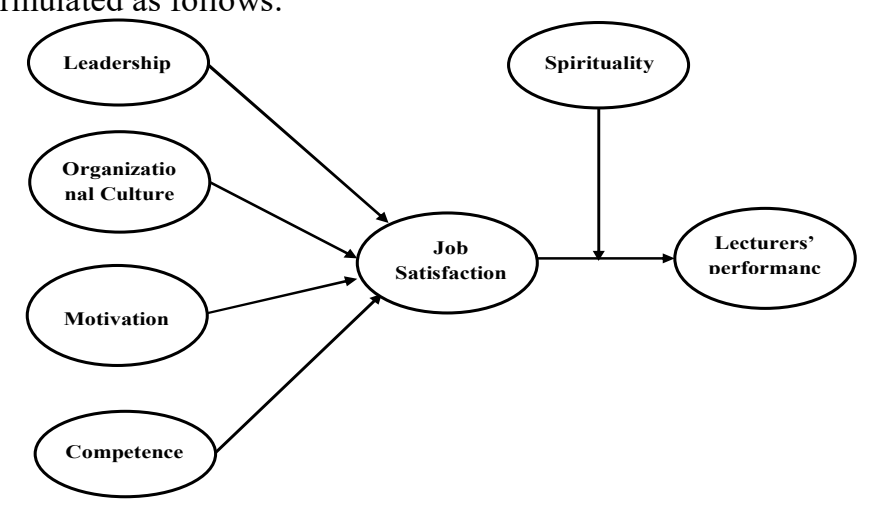

Fig.1. Research Model

1. Do leadership, organizational culture, motivation and competence affect the job satisfaction of lecturers?

2. Does job satisfaction affect the performance of lecturers?

3. Does job satisfaction moderated by spirituality have an influence on lecturers' performance?

\section{Research Model}

Based on theoretical and research findings as empirical evidence and prior synthesis, the research design usedis a causal relationship between leadership, organizational culture, motivation, work satisfaction, competence, spirituality and performance is presented in Figure 1.

\section{Research Design}

\subsection{Research Method}

This study was conducted to find out the influence of leadership, culture, spirituality, motivation, and competence which was expected to have an effect toward job satisfaction and to have a significant influence on the performance of private higher education lecturers in South Sumatra. In this study,non experimental research design was used. This study was descriptive study where the causes of the object of the study were discovered and described, and it was causal in which each variable was tested to measure the influence of leadership, culture, motivation and competence which was expected to influence job satisfaction, spiritual, and lecturers' performance as dependent variables significantly. 


\subsection{Population And Sample}

Population in this research was 4085 lecturers at private higher education in Kopertis Region II area (South Sumatra Province, Lampung, Bengkulu and Bangka Belitung Provinces). An approach proposed by Roscoe was used in selecting the sample (Roscoe 1975, in now, 2003). Theresearch used multivariate analysis (including multivariate linear regression analysis), sample size should be several times larger (10 times recommended) than the number of variables analyzed. It is also suggested that the appropriate sample size for research is greater than 30 and less than 500. There were 250 lecturers as the sample of the research. Random sampling technique was used to select 250 lecturers domiciled in the Province of South Sumatra, Lampung, Bengkulu and Bangka Belitung Provinces from 109 private higher educations in Kopertis Region II.

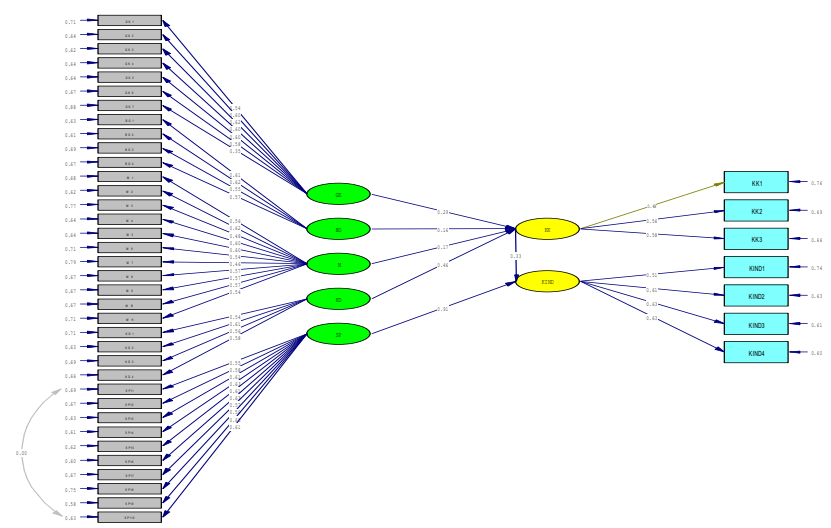

Fig.2. Figure 2: Loading factor Diagram of Each Indicator of Research Design.

\subsection{Technique of Analyzing Data}

Data were collected from questionnaire distribution and secondary data collections were done in 4 steps: editing, entry, tabulation and data analysis using Microsoft Excel 2007 and SPSS 20 version and Lisrel applications 8.70 version. Because this was a causality research, then statistical test tool was used on the research model to test the hypotheses. The validity and reliability of the test were calculated before administering the instruments.

\section{Results And Discussions}

In Lisrel format, model conformity testing was performed by using Goodness of Fit-Test (GFI). The two main measures of GFI are the p-count and Root Mean Square Error of Approximation (RMSEA) values. Based on the two GFI sizes, the model is said to fit with data if the model is able to produce p-arithmetic $\geq 0.05$ and RMSEA $\leq 0.08$. Based on the required statistical measurement, the resulting model listed in the table was designed to have met the requirements as a fit model with a Goodness of Fit Index value of 0.90 (the GFI value range $\geq 0.9$ is said to be a good fit model). Thus, the designed model could be used as a basis for making a generalization of the phenomenon studied. It was shown in figure 2 . 


\subsection{Model Feasibility Test}

Goodness of fit model feasibility test, from Gofabsolute size such as Chi Square probability, RMSEA size, GFI and RMR.

Table 1. Model Feasibility Test Output.

\begin{tabular}{c} 
Goodness of Fit Statistics \\
1.00) \\
Minimum Fit Function Chi-Square $=510.79(\mathrm{P}=$ \\
Root Mean Square Error of Approximation \\
(RMSEA) $=0.0$ \\
Normed Fit Index (NFI) $=0.84$ \\
Non-Normed Fit Index (NNFI) $=1.16$ \\
Comparative Fit Index (CFI) $=1.00$ \\
Incremental Fit Index (IFI) $=1.14$ \\
Relative Fit Index (RFI) $=0.83$ \\
Root Mean Square Residual (RMR) $=0.096$ \\
Standardized RMR $=0.048$ \\
Goodness of Fit Index (GFI) $=0.90$ \\
Adjusted Goodness of Fit Index (AGFI) $=0.89$ \\
\hline
\end{tabular}

Table 2. Result of SEM Model Feasibility Criteria

\begin{tabular}{|c|c|c|c|}
\hline GOODNESS-OF-FIT & $\begin{array}{l}\text { CUTT-OFF- } \\
\text { VALUE }\end{array}$ & $\begin{array}{l}\text { RES } \\
\text { ULT }\end{array}$ & NOTE \\
\hline Significance Probability (P-value) & $\geq 0,05$ & 1.000 & Good Fit \\
\hline RMR(Root Mean Square Residual) & $\leq 0,05$ or $\leq 0,1$ & 0.096 & Good Fit \\
\hline $\begin{array}{l}\text { RMSEA(Root Mean square Error of } \\
\text { Approximation) }\end{array}$ & $\leq 0,08$ & 0.00 & Good Fit \\
\hline GFI(Goodness of Fit) & $\geq 0,90$ & 0.90 & Good Fit \\
\hline AGFI(Adjusted Goodness of Fit Index) & $\geq 0,90$ & 0.89 & Marginal Fit \\
\hline CFI (Comparative Fit Index) & $\geq 0,90$ & 1.00 & Good Fit \\
\hline NFI (Normed Fit Index) & $\geq 0,95$ & 0.84 & Marginal Fit \\
\hline
\end{tabular}

goodness of fit, for absolute GoF size such as Chi Square probability $1,000 \geq 0,05$ (good fit), RMSEA size 0,00 (good fit), GFI 0,9 (Good fit) and RMR 0.096 (Good Fit). Almost allGoF incremental size(good fit).

\subsection{The Influence of Leadership, Organizational Culture, Motivation and Competence to Lecturer Job Satisfaction.}

In the output diagram of t-values, each indicator in the research model showed the tstatistical value for all models. An indicator is significant if the value of t-obtained is greater than the value of t-table at the error level of 0.05 that is equal to 1.96 (Hair et al., 1995), (Roscoe, 1975). Lisrel output in the form of path diagrams that show the red color indicates not significant while the colored shows significant. The result of SEM analysis showed the influence of the leadership style on job satisfaction. The value of t-obtained was $1.92<\alpha 1.96$, meaning that leadership does not significantly influence the working decision, so every improvement of leadership style in private higher education in Kopertis Region II, South Sumatra does not significantly improve job satisfaction of lecturers. Organizational culture has 
no significant effect on working decision, t-value was $1.02<\alpha 1.96$, meaning organizational culture has no significant effect on working decision, private higher education in the working environment of Kopertis Region II, South Sumatra does not significantly increase job satisfaction of the lecturers. For motivation on job satisfaction, t-obtained value was $1.43<\alpha 1.96$, meaning motivation does not significantly influence working decision. It means every improvement of motivation in private higher education work environment in Kopertis Region II, South Sumatra does not significantly improve job satisfaction of lecturers. For lecturer competence on job satisfaction, t-obtained value was 2.26> $\alpha$ 1.96.It means lecturer competence significantly influencesthe job satisfaction, so that every increase of lecturers competence in private higher education working environment in Kopertis Region II,South Sumatrahas an effect to significantly increase thejob satisfaction of lecturer.

\subsection{Model Match Test}

Goodness of fit results, for absolute GoF size, were Chi Square probability $1,000 \geq 0,05$ (good fit), RMSEA 0,00 (good fit), GFI 0,9 (Good fit) and RMR 0.096 (Good Fit). Almost all GoF incremental sizes (good fit) from the data showed that, simultaneously, leadership style, organizational culture, motivation, and lecturer competence significantly influence lecturer's performance at private higher education working environment in Kopertis Region II, South Sumatra.

With the model:

Job Satisfaction $=0.29 *$ Leadership Style $+0.16 *$ Organizational Culture $+0.17 *$ Motivation $+0.46 *$ Lecturer Competency.

Simultaneously, it means that leadership style, organizational culture, motivation, and lecturer competence have a significant influence on job satisfaction, so that every improvement of leadership style, organizational culture, motivation, and lecturer competence in private higher education working environment in Kopertis Region II, South Sumatra significantly improves job satisfaction of lecturers. This is in accordance with the research results of Kotter and Eskett (1992) in Stoner et al. (1996) which shows that organizational culture has a strong impact and greater performance of the organization. The study has four conclusions:

1. Corporate culture can have a significant impact on corporate economic performance in the

long run.

2. Corporate culture may even be a more important factor in determining the success or failure of the company in the next decade.

3. Corporate culture that hinders a strong financial performance over the long term is not uncommon; it develops easily, even in companies full of wise and clever people.

4. Although difficult to change, corporate culture can be changed to further improve performance

\section{Conclusion}

Conclusion that could be taken based on result of data analysis of Job satisfaction; reflected and the influence of lecturers' interaction with spirituality on the performance of lecturers are:

1. Simultaneously, leadership style, organizational culture, motivation, and lecturer competence significantly influence job satisfaction, so that every improvement of 
leadership style, organizational culture, motivation, and lecturer competence at private higher education in Kopertis Region II of South Sumatra, significantly improve lecturer job satisfaction.

2. Partially, leadership has no significant influence on job satisfaction, so that every increase of leadership style in private higher education working environment in Kopertis Region II, South Sumatra is not too significant to improve job satisfaction of lecturer. Organizational culture does not significantly influence job satisfaction, so that every improvement of organizational culture in private higher education in the working environment in Kopertis Region II of South Sumatra does not significantly influence job satisfaction of lecturers. Motivation does not significantly affect the Working Decision; it means that every improvement of motivation in private higher education in the working environment in Kopertis Region II of South Sumatra is not too significant to improve job satisfaction of lecturers. Lecturer competence significantly influences job satisfaction, so that every increase of lecturer competence in private higher education in working environment in Kopertis Region II, South Sumatra has significant effect to improve job satisfaction of lecturer.

3. Job Satisfaction has a significant effect on lecturers' performance, so that every increase of job satisfaction at private higher education in working environment in Kopertis Region II, South Sumatra significantly influences lecturers' performance.

\section{Acknowledgements}

The researchers would like to thank to the rector of UniversitasTamansiswa Palembang for the motivation and financial support for the implementation of this research. Researchers are also grateful to the parties who involved in the process of collecting and processing the data until this paper can be completed.

\section{References}

[1] Ali, M. (2013) 'Model of Lending Decisions on Small and Medium enterprise: Case Study in the South Sumatera', in International Conference on Managing the Asian Century.

[2] Chen, L. (2004) 'Examining the effect of organization culture and leadership behaviors on organizational commitment, job satisfaction and job performance at small and middle firms of Taiwan.', Journal of American Academy of Business, 5(1/2), pp. 432 438.

[3] Davis, K. and Newstrom, J. W. (1997) Organizational Behavior: Human Behavior at Work (McGraw-Hill series in management). 9th Editio. New Delhi: McGraw-Hill.

[4] Delobbe, N. (2002) 'Measuring core dimensions of organizational culture : A review of research and development of a new instrument', Culture, pp. 1-23.

[5] Gibson, J. L. et al. (2014) Organizations - Behavior, Structurem Processes, Igarss 2014. doi: 10.1007/s13398-014-0173-7.2.

[6] Hair, J. F. et al. (1995) Multivariate Data Analysis: With Readings. 4th Editio. Prentice Hall International, Inc.

[7] Hukpati, C. a M. a (2009) 'Transformational Leadership and Teacher Job Satisfaction: a Comparative Study of Private and Public Tertiary Institutions in Ghana .', Population (English Edition).

[8] King, D. B. and Decicco, T. L. (2009) 'A Viable Model and Self-Report Measure of 
Spiritual Intelligence', (2000), pp. 68-85.

[9] Moon, M. J. (2000) 'Organizational Commitment Revisited in New Public Management: Motivation, Organizational Culture, Sector, and Managerial Level', Public Performance \& Management Review, 24(2), pp. 177-194. doi: $10.2307 / 3381267$. 
Roscoe, J. T. (1975) Fundamental Research Statistics for the Behavioral Sciences. 2nd editio. New York: Holt Rinehart \& Winston.

Selman, V. et al. (2005) 'Spiritual-Intelligence/-Quotient', College Teaching Methods \& Styles Journal, 1(3), pp. 23-30.

Spencer, L. M. and Spencer, S. M. (1993) Competence models for superior performance.

Government Rule RI. No 37, 2009 About Lectures Function. 